\title{
A Comprehensive Model Of Customer Satisfaction In Hospitality And Tourism: Strategic Implications For Management
}

\author{
Robert Christie Mill, (E-mail: rmill@du.edu), University of Denver
}

\begin{abstract}
Providing and maintaining customer satisfaction is one of the most important challenges facing business today. Although this is a relatively new concept, research into this area has grown since the early 1980s.

One ongoing debate in consumer satisfaction circles is the extent to which it is a cognitive process or an emotional state. The two theories that best explain customer satisfaction are disconfirmation paradigm and expectancy-value concept. Disconfirmation theory postulates that customers compare a new service experience with a standard they have developed. Their belief about the service is determined by how well it measures up to this standard. According to expectancy-value theory customers often make some judgment about a product, its benefits, and the likely outcomes of using the product. People will learn to perform behavior that they expect will lead to positive outcomes.
\end{abstract}

There remains a need to provide a direct link between satisfaction and purchase. Some models indicate a link between satisfaction and repeat purchase intention but not yet to actual purchase. The most widely used model to translate theories of customer satisfaction into management practice is that of SERVQUAL. In this model service quality is defined as the difference between customer expectations and customer perception of service received.

It is proposed that, at this time, the SERVQUAL model presents the best mechanism to explain customer satisfaction in hospitality and tourism. A detailed examination of the model is provided together with suggested areas for further research to improve its applicability to hospitality and tourism.

\section{Importance of Customer Satisfaction}

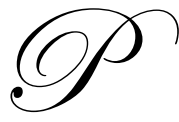

roviding and maintaining customer satisfaction is one of the most important challenges facing business today (Band 1978, Bitner 1990, Oliver \& DeSarbo 1988, Parasuraman et al, 1988, Kandampully, J., Mok, C., and Sparks, B., 2001). However, this is a relatively new concept. During the 1970s firms did not recognize customer satisfaction as a problem (Barsky 1992). The United States was "succeeding reasonably well in providing acceptable levels of satisfaction to the buying public" and "consumers find enjoyment and satisfaction in their buying experiences...considerably more often than they find difficulty and discontent" (Westbrook et al, 1978). As a result demand was met by technical product innovations rather than service improvement (Barsky 1990). In recent years the idea that the level of customer satisfaction is not at an acceptable level was seen as a growing concern. Foundation studies include those by Anderson (1973) and Olshavsky and Miller (1972).

Readers with comments or questions are encouraged to contact the author via email. 
Research into this area has grown since the early 1980s. For example, a clear trade off between customer satisfaction and potential repeat business has been demonstrated. In the airline business it has been shown that each 0.2 increase in overall rating on a standard five point scale indicates a 6-12 percent higher level of repeat business, depending on the different classes of service (Morris 1992).

A milestone in the recognition of the importance of customer satisfaction was the creation in 1987 of the Malcolm Baldrige National Quality Award, the highest level of national recognition for performance excellence that a U.S. company can receive. The major focus of the Award is on results, including customer satisfaction.

In most industries (Davidow and Uttal, 1989) the battle for customers moves from tangibles to intangibles. As the market matures competitors offer similar features and the battle moves to price. Inefficient operators drop out and quality becomes the most important consideration. Thereafter the emphasis turns to customer service as a way of satisfying customers. This is where we are today.

\section{Theories of Customer Satisfaction}

There is no universally accepted definition of customer satisfaction (McCollough, 2000). One ongoing debate in consumer satisfaction circles is the extent to which it is a cognitive process or an emotional state. Howard and Sheth (1969) define satisfaction as "the buyer's cognitive state of being adequately or inadequately rewarded for the sacrifice he has undergone." Engel and Blackwood (1982) see it as "an evaluation (cognitive) that the chosen alternative is consistent with prior beliefs with respect to that alternative." It is probably a complex human process involving "extensive cognitive, affective and other undiscovered psychological and physiological dynamics" (Oh and Parks, 1997).

\section{Disconfirmation paradigm}

The two theories that best explain customer satisfaction are disconfirmation paradigm and expectancyvalue concept (Barsky 1992). Both are widely accepted theories of consumer behavior though neither addresses the relationship between customer satisfaction and actual purchase behavior.

Disconfirmation theory indicates that customers compare a new service experience with a standard they have developed. Their belief about the service is determined by how well it measures up to this standard. The theory presumes that customers make purchases based on their expectations, attitudes, and intentions (Oliver 1980). Later, during or after consumption, a perception of performance occurs as customers evaluate the experience. The process is completed when customers compare the actual service performance with their pre-experience standard (Beardon \& Teel 1993, Cardozo 1965, Day 1977, Oliver 1980) or expectation. The result is confirmation, satisfaction, or dissatisfaction.

There are four components to this paradigm - expectations, perceived performance, disconfirmation, satisfaction. The level of expectations represents pre-consumption expectation. Performance refers to the customer's perception of service. Disconfirmation results if there is a discrepancy between expectations and performance. Finally, satisfaction is determined by combining the satisfaction outcomes for the various attributes of the service. The first three components affect satisfaction but it is not determined whether or not these lead to satisfaction or dissatisfaction. Neither is there consensus on how the variables interrelate.

In most studies involving disconfirmation expectations are considered the standard consumers use and are compared to such things as:

1. Equitable performance - formed by the consumer based on the individual's costs or investment and anticipated rewards. (Liechy \& Churchill 1979, Miller 1979, Woodruff et al, 1983);

2. Ideal product or service performance - the consumer's ideal level or service performance (Liechy \& Churchill 1979, Miller 1979); 
3. Experience-based norms - the desired level of performance based on experience with competitors (Cadotte et al, 1987); this concept is generally associated with tangible products and may, therefore, be different when dealing with services.

4. Relationship quality - quality of the relationship between salesperson and customer leads to satisfaction and significantly affects sales (Crosby et al, 1990). This idea extends the impact of media and word of mouth on the relationship. Price is often regarded as an indicator of quality. Many customers perceive higher priced items are of higher quality. Price tends to play a larger part when customer is less familiar with service.

According to Oliver (1980), the following operational assumptions are part of the theory:

1. When expectations are high and performance is low, moderately low disconfirmation will result - i.e. expectations are not met. High performance will result in moderately high level of expectations being met (EM) due to confirmation.

2. When expectations are low, low performance will result in very low EM ratings, while high performance will result in very high EM ratings due to a surprise effect.

3. If expectations match performance at any level, conformation will result and EM will represent the value of the expectations/ performance level.

\section{Expectancy-value theory}

According to expectancy-value theory customers often make some judgment about a product, its benefits, and the likely outcomes of using the product. People will learn to perform behavior that they expect will lead to positive outcomes (Tokman, 1932). Their overall attitude is a function of beliefs about an object's attributes and the strength of these beliefs. The impact of attribute importance on consumer decision making is also widely recognized (Heeler et al, 1979).

The relationship has been summarized as follows:

$\mathrm{Q}=\mathrm{Ii}(\mathrm{Pi}-\mathrm{Ei})($ Carmen 1990), where

$\mathrm{Q}$ is the overall quality; I is the importance of service attribute I; the sum is over the number of service attributes; P is the perception; $\mathrm{E}$ is expectation.

There remains a need to provide a direct link between satisfaction and purchase (Barsky, 1990). Some models indicate a link between satisfaction and repeat purchase intention but not yet to actual purchase.

\section{SERVQUAL}

The most widely used model to translate theories of customer satisfaction into management practice is that of SERVQUAL (Soutar, 2001). In this model service quality is defined as the difference between customer expectations and customer perception of service received. The "gap" in service quality occurs when the perception of service received is less than what is expected (Zeithaml et al, 1990).

\section{Problems with SERVQUAL}

SERVQUAL has been challenged on several grounds (Fick and Ritchie, 1991, Johns, 1996, Bennington and Cumane, 1998):

1. Negatively worded statement sets. In accordance with generally accepted scale construction, half of the 
statement sets were worded negatively. In one study (Fick and Ritchie, 1991) the mean scores for dimensions worded negatively were lower for every service segment than were the mean scores for the positively worded dimensions. This was also the case with the original SERVQUAL model in all but one case. It is concluded that consumers become confused or less likely to answer at the extreme ends if the scale when responding to negatively worded statements. Also, respondents have a tendency to respond systematically in the affirmative in many situations, the so-called "acquiescence response set." Therefore it is not appropriate to compare mean expectations and perception scores of dimensions that have statement sets worded differently. In their later work, Parasuraman et al have eliminated negatively worded statements.

2. Quality of service management construct. The model assumes that service quality equals perception minus expectations. A higher score translates into higher quality. However, the Likert scale used does not appear to have the ability to distinguish between subtle differences in levels of expectations and perceptions. Both scores were very high. Consumers may not internalize their judgment about expectations and perceptions in a way consistent with the capturing of those judgments on a seven point Likert scale (Fick and Ritchie, 1991).

3. Difference scores. Concern has been raised about the issues of reliability, systematic correlation of the construct with its components, and systematic relationships to any random errors of measurement. The question has arisen as to whether or not confirmatory factor analysis, linear regression models and multiple regression can be used to deal with this problem? Researchers believe that Confirmatory Factor Analysis is better than Exploratory Factor Analysis for the lodging industry (Knutson et al, 1991).

4. Measurement of quality. Application of the scale suggests that items categorized as measuring perceptions of performance may be more accurately categorized as measuring the quality of service provided by firms. Computed quality construct is not the most appropriate means of evaluating perceived service quality. Mean perception of performance provides as good if not better evaluation of perceived service than computed quality score (Cronin and Taylor, 1994, Johns 1996). The SERVPERF model, however, does not have the theoretical base provided by SERVQUAL.

These arguments do not invalidate the SERVQUAL but they do have an effect on the interpretations that can be drawn.

\section{The SERQUAL Model}

It is proposed that, at this time, the SERVQUAL model presents the best mechanism to explain customer satisfaction in hospitality and tourism. The remainder of this paper is devoted to a detailed examination of the model together with suggested areas for further research to improve its applicability to hospitality and tourism.

The gap between what customers expect and what they perceive they get is for one or more of the following reasons (Zeithaml et al, 1990):

- Gap 1: Management does not know what guests expect.

- Gap 2: Management is not willing or able to put the systems in place to match or exceed customer expectations -- service-quality standards are not developed.

- $\quad$ Gap 3: The service-performance gap - when employees are unable and/or unwilling to perform the service at the desired level.

- $\quad$ Gap 4: When promises do not match delivery.

\section{A Strategic Approach}

Where is the manager to begin? A sequential five step approach is suggested:

1. Identify whether or not a problem exists. 
2. Manage customer expectations so they are realistic with the service offering. (Gap 4)

3. Identify customer needs and expectations of quality service. (Gap 1)

4. $\quad$ Develop service quality standards based on customer expectations. (Gap 2)

5. Re-evaluate the human resource system to hire, train, and motivate employees who are willing and able to deliver quality service. (Gap3)

\section{Is there a problem?}

A problem with customer satisfaction exists when customer perception of the service delivered is less than their expectations of the service expected. According to Zeithaml et al (1990) there are five dimensions of service. They are:

1. Tangibles: Appearance of physical facilities, equipment, personnel, and communication materials.

2. Reliability: Ability to perform the promised service dependably and accurately.

3. $\quad$ Responsiveness: Willingness to help customers and provide prompt service.

4. Assurance: Knowledge and courtesy of employees and their ability to convey trust and confidence.

5. Empathy: Caring, individualized attention the company provides its customers.

Tangibles in a restaurant setting might refer to the cleanliness of the restrooms, the personal hygiene of the employees, and the ease with which the bill can be understood. Reliability covers such things as a table being available at the time the customer was told it would be available, a steak being cooked as ordered, and the bill being free of errors. When employees correct problems immediately or when they show a willingness to answer customer questions about the menu the company is demonstrating their responsiveness to the customer. Assurance comes from such things as employees demonstrating their knowledge and competence, being polite and friendly, and offering guarantees of satisfaction. Empathy is shown by how approachable employees are, talking to customers in language they can understand, and making an effort to understand the needs of the customer.

In one study applying SERVQUAL to a hotel setting (Knutson et al 1990) reliability is seen as the most critical dimension (do not make promises you cannot keep) - followed by assurance - the ability of employees to convey trust and confidence. The fourth element is tangibles (e.g. employee appearance) followed, fifth, by empathy. Customers have high expectations for reliability and assurance. Since the means are high and deviations are small, it appears that there is little discriminatory power within these two dimensions. Therefore they are dissatisfiers rather than satisfiers - that is people are unhappy if they are absent but not happy is they are present.

In a restaurant application (Bojanic et al, 1994) empathy was segmented into knowing the customer and access. The highest expectation scores were assurance 6.4; reliability 6.27; tangibles 6.17 while the lowest was knowing the customer 5.31; responsiveness from 5.71 and access to 5.81 the server. Perception was consistently lower than expectations. Largest gaps were found in reliability and responsiveness; the smallest in knowing the customer.

In another study of tourism industries (Fick and Ritchie, 1991) the two most important expectations concerning service were (on a scale of 1-7):

1. $\quad$ Airlines - reliability (6.46) and assurance (6.44)

2. Hotels - reliability (6.43) and assurance (6.38)

3. Restaurants - assurance (6.33) and reliability (6.18)

4. Ski areas - assurance (6.31) and reliability (6.11)

For performance, highest ratings were:

1. Airlines - tangibles (5.9) and assurance (5.53)

2. Hotels - tangibles (5.49) and assurance (5.53)

3. Restaurants - tangibles (5.69) and assurance (5.43)

4. Ski areas - tangibles (5.41) and assurance (5.160) 


\section{Managing Customer Expectations}

Customer expectations have to be raised to a level high enough to motivate people to leave home for the restaurant, the hotel or the vacation destination. It is more difficult to sell a service than a part for a car because, if the part does not work, it can be returned and replaced. This is not true for a restaurant meal, a hotel stay or a vacation, which is consumed before the customer can determine whether or not it is acceptable. This means that expectations have to be raised even higher for an intangible product - food plus service - than for a tangible good. This can lead to a tendency to promise too much in an attempt to get the customers in the door. When customers come in with unrealistic expectations employees may not be able to deliver, no matter how well they perform.

A arises because of a lack of communication between those who sell the experience and those who are expected to deliver it. Employees who cook and serve the food must be involved in marketing decisions to provide a reality check to those who plan the advertising. By the same token employees should see what customers are being told in advertisements for the restaurant, hotel or tourist destination in order that they know what customers are being promised - promises they will be expected to deliver on.

When a problem with customer satisfaction has been identified the first step is to bring customer expectations into line with what is being offered. At first glance this seems destructive to the business. However, the longer the company develops customer expectations through its advertising that cannot be met the more customers will be dissatisfied with their experiences. Care must be taken, however, to ensure that the lowered customer expectations are high enough to induce patronage.

\section{Identifying Customer Needs and Expectations}

Management does not know what is important to the guest for one or more of three reasons. First, the company lacks a marketing research orientation. This is the extent to which managers make an effort to understand customers' needs and expectations through formal and informal information-gathering activities. It may be that there is insufficient marketing research done; that there is an inadequate use of research findings; and/or there is an overall lack of interaction between management and customers.

A second possibility is that there is inadequate upward communication. This is a measure of the extent to which top management seeks, stimulates, and facilitates the flow of information from employees at lower levels. Finally, too many levels of management may cause the problem. This is a direct reflection of the number of managerial levels between the topmost and bottommost positions.

To address these concerns the company needs to institute ongoing market research, listen to their employees and reduce the levels of management within the organization. The best way to find out what is important to customers is to ask the customer! As obvious as this seems many people think that they know best when it comes to satisfying the customer. Research should be conducted on an ongoing basis, both formally and informally, to understand the needs, motives, and expectations of existing and potential customers.

Too often communication is primarily downward from management to employee. Managers may think that they should know the answers to operational problems without having to ask employees. For others it is beneath them to seek guidance from their subordinates. Yet front-of-the-house employees have much more contact with customers than does management. They are in the best position to identify which features of the operation and menu are pleasing to customers and which are turning them off. To put such a system in place requires overt action on the part of the manager. Suggestions have to be encouraged from customer-contact employees. A system put in place to reward any idea about improving service will produce more ideas than a system to reward only good (in the eyes of management) ideas. Good ideas have to be rewarded and implemented if management wants the flow of ideas to continue.

The success of such a system will depend, to a large extent, on how management handles bad news - feedback about service problems. If the orientation is to find out who messed up and to punish the offender employees will be re- 
luctant to report any bad news to management. On the other hand, if the emphasis is on finding out why the mistake happened and improving procedures to ensure it does not happen again employees will be more willing to share with management.

The further that decision makers are from the customer the greater is the likelihood that they will be out of touch with what is important to the customer. Many companies are flattening their organizational structure, getting rid of middle management, in a dual attempt to cut costs and get closer to the customer.

\section{Set Service Quality Standards}

Even if management knows what is important to the guest, they may be unwilling or unable put the systems in place to match or exceed customer expectations. It may be that there is an insufficient commitment to service quality - a measure of the extent to which management views service quality as a key strategic goal. Then, again, many managers do not believe that customer expectations can be met when it comes to the intangibility of "excellent service." Because of the difficulty in standardizing service tasks, there is disagreement as to whether or not hard and soft technology can be useful to service companies. Finally, even if service quality goals are set, they may be based on company standards rather than on customer standards and expectations.

According to Zeithaml et al (1990) effective service-quality goals are:

1. Designed to meet customers' expectations:

2. Specific.

3. Accepted by employees.

4. Cover important job dimensions.

5. Measured and reviewed with appropriate feedback.

6. Challenging but realistic.

J.C. Penney has been credited with saying "If you satisfy the customer, but fail to get the profit, you'll soon be out of customers; but if you get the profit, but fail to satisfy the customers, you'll soon be out of customers." The question is "which comes first - profits or customers?" Restaurants are in business to make money. Will the provision of quality service result in profitability? Peters and Waterman (1982) compared the bottom line profitability of companies that stressed financial goals - return on investment, net profit etc. - with those that stressed non-financial goals such as cleanliness, quality and service. They found that the companies that stressed non-financial goals actually produced better bottom line results than companies that stressed financial goals. A major reason, they argued, was that employees could relate more to such things as quality and service than to return on investment and were more likely to support a program to improve these things than to get behind an effort to improve profit.

\section{Re-evaluate the Human Resource System}

A problem arises when quality standards have been developed but employees do not deliver on them. The moment of truth, in this case, is the service encounter. The service encounter between customers and employees should not simply "occur." Management is responsible for ensuring that the encounter is planned, organized and, to the extent it can be, controlled in order to ensure customer satisfaction.

Hollander has noted that a review of the historical literature on service uncovers certain features of the service encounter that persist (Hollander, 1985). Service encounters and purchases are considered important to the customer and routine to the service provider. Employees serve scores of customers a day. For the customer that meal out may be a once-a-week occurrence. It is difficult for the employee to generate the same level of enthusiasm for every customer that each customer has for the occasion.

Second, many service employees resent some or all of their customers. This may be due to one of a number of factors. For some employees there is the feeling that customers do not appreciate all the work that is necessary to provide good service. Others feel lower in status because they are serving the customer and may resent their job because of 
it. In some cases the difficult or rude behavior of customers generates negative feelings on the part of the employee.

Third, many customers want special treatment in a service situation. Perhaps they feel the need to throw their weight around or they feel that, by demanding special treatment, they are accorded more status. This places the employee in a difficult situation. They probably resent the fact that everyone pays for equally good service while some expect to receive more what everyone else is getting.

Fourth, customers have differing needs and wants regarding service. Some prefer an unobtrusive manner of service while others revel in a fawning, attentive style. It is up to the employee to match the level of service expected to the service delivered. Related to customer expectations is evidence that factors such as the age, sex, and dress of the employee affect customer perceptions of whether or not the service to be provided will be satisfactory. A customer in a first class restaurant may feel that "proper" service in such a setting would come from an older, male waiter. A younger, female waitress - no matter how skilled - may well set up negative initial reactions from the customer.

Lastly, Hollander notes that many service encounters appear successful - or at least tolerable - because customers bring lowered expectations to the service encounter and employees develop coping strategies to deal with potential problems arising from the points made above.

Poor employee-job fit refers to the match between the skill of the employees and their jobs. This brings up the "nature versus nurture" debate. Do service performers have innate abilities, which must be hired, or can any employee be trained and motivated to become a better service performer?

A strategic approach to getting employees to deliver quality service means recognizing the importance of employees, hiring people who have the potential to give quality service, training them in areas in which they are deficient, and providing a climate that is likely to produce motivated employees.

As far as management is concerned, the customer comes second. The first priority of management is the employee. If management takes care of the employees, the employees are more likely to take care of the customers. Customers will be satisfied, spend money, come back, and tell their friends. That, in turn, will provide the revenues that will keep the owners or stockholders happy.

We need to apply the same tools we use in marketing to the customer when we deal with our employees. There is a similarity. Customers vote with their dollars; employees vote with their feet. Bell and Winters (1993) contrast Product Marketing and Human Resource Marketing in this way. Just as we have customers so we have employees; we need to think of jobs in the same way we do products; brand image equates to employee morale; brand switching is the same as turnover; a trial purchase can be though of as recruiting and a repeat purchase as retention.

By treating the employee as number one and applying the marketing thought process to how we deal with employees business will be able to hire, train and motivate the type of employee who can and will deliver superior quality service to the customer.

The key here is to do a better job of selecting employees who exhibit service potential. Managers need to hire employees who will treat customers as their number one concern. At the same time the Beth Israel Medical Center in New York was looking for a "Director of Guest Relations" a nationally recognized medical clinic was advertising in this way: "Wanted - Complaints Clerk." Since we are in competition with many other industries for employees it is time to use customer-advertising techniques to the employees are hired. Several years ago Burger King, looking for part-time employees, ran huge billboards aimed at mothers of young children. Their slogan "Have it your way" suggested their flexibility in arranging hours for employees. At the same time they used the same tag line in advertising for employees as they did in seeking customers.

Studies of customer-oriented employees (Fromm and Schlesinger, 1994) indicate that they share certain characteristics. They tend to be early risers with a high energy level and type-A personalities. They remember their early work experiences with a passion and had a good work ethic that was developed early. Good natured and 
charming, they love their work and are easy to like. They share an ability to compartmentalize their moods, not allowing setbacks in their personal lives to intrude upon their workplace mood. They display consistent good humor, trust their customers, and take a long-term view of the customer-employee relationship. Combining a talent for seeing what was missing and racing to supply it, they are never satisfied with their own performance but, at the same time, are content to be front-line employees

Employees who are successful are able to adapt their behavior to that of the guest and respond accordingly. So-called "flexible-focus" individuals can be found by how they score on the Central Life Interest Measure. Adaptable people are low in dogmatism, high in tolerance for ambiguity and/or high on self-monitoring. Simulations, assessment center techniques, and situational interviews are ways to determine the existence of all of these.

First, it is necessary to identify what can be trained. Some authors (Fromm and Schlesinger, 1994) believe two things than can and should be taught are problem solving and customer orientation. Training customer orientation means giving employees a clear set of goals that allows them to focus on what customers expect. Others agree with training employees to solve problems by pushing levels of decision making as low as possible, giving them the authority to put that ability into practice.

Employees possess four types of learning skills. Learning skills can be defined as accommodative learning skills, encompassing a set of competencies; divergent skills, associated with valuing skills; assimilation learning skills, related to thinking competencies; and convergent learning skills, associated with decision skills. It is hypothesized that the more hedonistic the service level offered by an organization, the higher the divergent, assimilation and convergent learning skills required in an employee and the lower the necessity for accommodative learning skills. One the other hand, the more utilitarian the service level offered by an organization, the lower the divergent, assimilation, and convergent learning skills required in an employee and the greater the necessity for accommodative learning skills (Crawford-Welch 1989).

Managers cannot directly motivate employees - motivation comes from within the employee. However, managers can set the climate within the organization that can determine the extent to which employees are more or less likely to be motivated to perform.

Davidow and Uttal (1989) believe that most of the manager's time should be spent in communicating values. The more uncertain the task, the more employees rely on values instead of formal controls to guide their behavior. This is where company culture comes in - the values, beliefs and norms shared by a group of people. Shared values and beliefs have to be developed to take the place of policy and procedure manuals. Formal controls are progressively less effective the more decentralized a customer service organization becomes, the more contact employees have with customers, and the more customers act as co-producers.

Service leaders treat employees as they wish employees to treat customers. They express the same values in their dealing with front-line employees they want these employees to show in their dealings with the customers. They realize the world they create for employees is the world their employees will create for the customers.

Motivating employees means creating an environment that fosters the best possible work and the best possible service. This involves two steps - finding out what is important to the employees and designing their jobs in ways that allow them to achieve what is important to them. Poorly designed jobs result in such things as role ambiguity, role conflict, giving the employees inadequate tools and control to perform the job and inappropriate supervisory control systems (Zeithaml et al, 1989).

Role ambiguity is the extent to which employees are uncertain about what managers expect from them and how to satisfy those expectations. The key is to provide role clarity by such things as giving employees accurate information about their roles in the company; letting them know how well they are performing compared to the standards and expectations set for them; instilling confidence and competence by training them in the skills needed to satisfy customers - both technical training and training in interpersonal skills and teaching employees about customers. 
Employees are often also given ambiguous information from the customer. The more this occurs, the more likely the employee will not have a "standard" pre-determined response and the more likely the transaction cost will be higher and organizational performance will go down unless the employee is permitted to use self-management skills (Crawford-Welch 1989). Instead of attempting to alter employee values, attitudes and beliefs, selfmanagement should focus on giving employee interpersonal skills through behavior modification. The importance of non-verbal skills interpersonal skills increases the greater the customer involvement in the service encounter and as the number of customers the employee must deal with increases (Crawford-Welch 1989).

Role conflict is the extent to which employees perceive that they cannot satisfy all the demands of all the individuals (internal and external customers) they must serve. Role conflict can be eliminated by defining service roles and standards in terms of customers' expectations; reinforcing change with other human resource systems; training employees in priority setting and time management; assigning frequent breaks and varied tasks.

The term contact overload has been coined to refer to the emotional "work" that comes from having to deal with too many customers over a prolonged period of time. The result can be emotional burnout resulting in emotionless emotions. The problem is compounded by the fact that servers have to rely upon other employees in order to provide excellent service. When items are held up in the kitchen or are cooked improperly, the result in a less than satisfactory experience for the customer through no fault of the employee.

Setting employee standards and behavior based on the expectations of customers rather than those of management can reduce role conflict. If employees know that, given a conflict between what management wants and what customers want, the customer prevails, they can go about their work with less confusion. Take, for example, the customer who complains that a steak is not cooked to their satisfaction. If employees know that the customer is always right, then neither server nor cook will attempt to argue with the customer. Servers will know that they can go back to the kitchen without getting an argument from the cook. Similarly, if in this situation, the server decides to make an adjustment in the customer's bill, they will know that they will be backed up by management rather than chided for "giving away something" and, thereby, increasing costs.

The more uncertainty in the service encounter, the greater the employee will turn to his/her internal cognitive framework as a behavioral guide. This will increase the necessity for self-management. If the employee does not have the interpersonal skills necessary to practice self-management in a high uncertainty situation, he/she will be less motivated to act in efficient manner. The usefulness of self-management will be negated (Crawford-Welch 1989).

Employees must be given the tools that will allow them to perform their jobs more effectively. Advances in technology have enabled servers to send customer orders to the kitchen by means of hand-held computers. As a result servers are able to stay on the floor attending to customer needs and make fewer trips to the kitchen. The efficiency of technology depends on degree of customer involvement in the production process, workflow uncertainties, and task uncertainties (Ishak et al, 1990). The less direct contact customers have in the production process, greater the potential for the technology to operate at peak efficiency (Chase 1978).

How appropriate is the evaluation and reward system in the company? If companies wish to improve service they need to set up a supervisory system that rewards employees who exhibit behaviors that are regarded as providing quality service. Puckett (1981) found management presumes satisfaction of employee needs is sufficient while employees consider satisfaction of emotional and psychological needs more important.

The extent to which employees perceive that they can act flexibly rather than by rote in problem situations encountered in providing services refers to the amount of control employees feel they have. Employees experience less stress in their jobs when they - the employees - feel that they have control over situations that occur in their work. Giving the server - or, for that matter, any employee - the authority to resolve the complaint is an example of employee empowerment. Employee empowerment entails pushing authority down to the lowest level possible. Instead of getting a manager to hear a complaint and to make a decision on how it should be resolved, the employee who gets the complaint 
owns that complaint and is responsible for solving it to the satisfaction of the customer. The result is a faster response to complaints and motivated employees who feel that they can "control" the delivery of quality service.

\section{Summary}

Satisfied customers are more likely to return and to tell friends and relatives about their positive experience. Satisfied customers are produced when the service provided (as perceived by the guest) is more than that expected by the guest. When the service provided is less than expected it is for one or more of several reasons - management does not know what is important to the customer; management is aware of what is important but fails to set service quality standards in the areas that are important; standards are set but employees fail to deliver on them; promises are made to guests that are not delivered.

By bringing service promises in line with what is currently being offered management begins to manage customer expectations. Research must then be conducted to identify what is important to the guest. Service quality standards are then set based on what is discovered. Finally a human resource system is developed that hires employees who possess service performer skills, trains them in behaviors likely to produce satisfied customers and designs their jobs such that they - the employees - are motivated to perform.

\section{References}

1. Adams, S. J. (1963). Towards an understanding of inequity. Journal of Abnormal and Social Psychology, 67, 422-36.

2. Anderson, R. E. (1973). Consumer dissatisfaction: The effects of disconfirmed expectancy on perceived product performance. Journal of Marketing Research, 10, 38-44.

3. Alpert, M.I. (1971). Identification of determinant attributes: A comparison of methods. Journal of Marketing Research, V111, 184-91.

4. Barsky, J. D. (1992). Customer satisfaction in the hotel industry: meaning and measurement. Hospitality Research Journal," 16 (1), 51-73.

5. Bell, R. A. \& Winter, L. C. (1993). Using marketing tools to improve employee relations. The Cornell Hotel and Restaurant Administration Quarterly, 34 (4), 38-42.

6. Bennington, L., and Cumane, J. (1998) Measuring service quality: a hybrid methodology. Total Quality Management (6) 395-406.

7. Bojanic, D. C. \& Rosen, L.D. (1994). Measuring service quality in restaurants: an application of the SERVQUAL instrument. Hospitality Research Journal, 18 (1), 3-14.

8. Crawford-Welch, S. (1989). Self-management in hospitality organizations: a conceptual analysis. Hospitality Education and Research Journal, 13 (3), 435-447.

9. Cronin, J.J. Jr. \& Taylor, A. (1994). SERVPERF versus SERVQUAL: reconciling performance-based and perception-minus-expectations measurement of service quality. Journal of Marketing, 58, 125-131.

10. Davidow, W. H. \& Uttal, B. (1989). Total customer service: the ultimate weapon. New York, Harper \& Row Publishers.

11. Engel, J.F. \& Blackwood. R.D. (1982). Consumer behavior. New York, Dryden Press.

12. Fick, G.R. \& Ritchie, J.R.B. (1991). Measuring service quality in the travel and tourism industry. Journal of Travel Research, 30 (2), 2-9.

13. Fromm, B. \& Schlesinger, L. (1994). The real heroes of business. New York, Doubleday.

14. Hollander, S.C. (1985). A historical perspective on the service encounter in Czepiel, J.A., Solomon, M.R. \& Surprenant, C.F. (Eds.). The service encounter: managing employee/customer interaction in service businesses. Lexington, MA, D.C. Heath and Company, pp. 48-53.

15. Howard, J.D. \& Sheth, J.N. (1969). The theory of buyer behavior. New York, John Wiley \& Sons.

16. Ishak, N.K. \& Olsen, M.D. (1990). A contingency approach to service delivery systems: a framework for analysis. Hospitality Research Journal, 14 (2), 47-56.

17. Johns, N. (1996). Measuring hospitality service quality. Paper presented as part of the international on-line hospitality research conference, 1996.

18. Kandampully, J., Mok, C., and Sparks, B. (eds.) Service quality management in hospitality, tourism, and 
leisure. New York, The Haworth Hospitality Press.

19. Knutson, B., Stevens, P., Wullaert, C., Patton, M. \& Yokoyama. F. (1990). Lodgserv: a service quality index for the lodging industry. Hospitality Research Journal, 14 (2), 277-284.

20. Knutson, B., Stevens, P., Patton, M., Wullaert, C., \& Yokoyama, F. (1991). Service expectation index: a discussion of confirmatory analysis and factor analysis as methods of index testing and refinement," Hospitality Research Journal, 413-419.

21. McCollough, M. A. (2000), The Effect of perceived Justice and Attributions Regarding Service Failure and Recovery on Post-Recovery Customer Satisfaction and Service Quality Attributes, 24 (4), 423-447.

22. Meehl, P. (1955). Classical versus statistical prediction. Minneapolis: University of Minnesota Press.

23. Mikes, P.S., \& Hulin, C. L. (1968). Use of importance as a weighing component of job satisfaction. Journal of Applied Psychology, 52, 394-98.

24. Miller, J. A. (1977). Studying satisfaction, modifying models, eliciting expectations, posing problems, and making meaningful measurements. In H. Keith Hunt (Ed.), Conceptualization and measurement of consumer satisfaction and dissatisfaction (pp. 72-91). Cambridge, MA: Marketing Science Institute.

25. Morris, Peter (1992). Emerging issues in international air transport, with special reference to marketing and research. Presentation to the Travel and Tourism Research Association.

26. Oh, Haemoon \& Parks, S.C. (1997). Customer satisfaction and service quality: a critical review of the literature and research implications for the hospitality industry. Hospitality Research Journal, 20(3), 35-64.

27. Oliver, R. L. (1980). A cognitive model of the antecedents and consequences of satisfaction decisions. Journal of Marketing Research, 17, 460-9.

28. Oliver, R.L., \& DeSarbo, W. S. (1988). Response determinants in satisfaction judgments. Journal of Consumer Research, 14, 495-507.

29. Olshavsky, R., \& Miller, J. A. (1972). Consumer expectations, product performance, and perceived product quality. Journal of Marketing Research, 9, 19-21.

30. Organ, D. W., \& Bateman, T. S. (1991). Organizational Behavior, New York Irwin.

31. Parasuraman, A., Zeithaml, V. A., \& Berry, L. L. (1988). SERVQUAL: A multi-item scale for measuring consumer perceptions of service quality. Journal of Retailing, 64, 12-40.

32. Peters, T.J. \& Waterman, R.W., Jr., (1982). In search of excellence: lessons from America's best run companies. New York, Harper \& Row.

33. Quelch, J. A. (1978). Behavioral measurement of the relative importance of product attributes: Process methodology and pilot application. Working Paper 180R, University of Western Ontario, School of Business Administration, London, Ontario, Canada.

34. Riteer, C. B. (1967). What influences purchases of color television? Journal of Retailing, 42, 25-31; 63-64.

35. Rosenberg, MJ. (1956). Cognitive structure and attitudinal affect. Journal of Abnormal and Social Psychology, 53, 356-72.

36. Ryan, M. J., \& Holbrook, M. B. (1982). Importance, elicitation order, and expectancy x value. Journal of Business Research, 10, 310.

37. Soutar, G.N. (2001). Service quality, customer satisfaction, and value: an examination of their relationships in Kandampully, J., Mok, C., and Sparks, B. (eds.) Service quality management in hospitality, tourism, and leisure. New York, The Haworth Hospitality Press, 103.

38. Tolman, E.C. (1932). Purposive behavior in animals and men. New York: Appleton-Century.

39. Trice, A. D., \& Layman, H. (1984). Improving guest surveys. The Cornell University Hotel and Restaurant Administration Quarterly, 25 (3), 10-13.

40. Vroom, V.H. (1964). Work and motivation. New York: John Wiley and Sons.

41. Westbrook, R. A., Newman, J. W., \& Taylor, J. R. (1978). Satisfaction/dissatisfaction in the purchase decision process. Journal of Marketing, October 59.

42. Woodruff, R. B., Cadotte, E. R., \& Jenkins, R. L. (1983). Modeling consumer satisfaction processes using experienced based norms. Journal of Marketing Research, 20, 296-304.

43. Zeithaml, Valarie A., Parasuraman, A., \&Berry, L.L. (1990). Delivering quality service: balancing customer perceptions and expectations. New York, The Free Press. 